\title{
BIODEGRADATION AND MECHANICAL BEHAVIOUR OF SINTERED COMPACTS OF Co-Cr ALLOY POWDER DOPED WITH $\mathrm{ZrO}_{2}$ USED IN DENTISTRY
}

\author{
Diana-Irinel Băilă, Oana-Cătălina Mocioiu, Roxana Truşcă, Adrian Surdu, Cătălin Zaharia, \\ Mihaela Bunea
}

Original scientific paper

Direct Metal Laser Sintering process is modern technology and is used in different industries, inclusive in medicine industry. The purpose of this study was to obtain sintered compacts of Co-Cr powder doped with $\mathrm{ZrO}_{2}$ in order to improve the bioactivity of the implants and the behavior in vitro after immersion in simulated biological fluid (SBF) for 21 days. Co-Cr powders (ST2724G) were used to realize one reference sample of Co-Cr and 4 compacts of Co-Cr doped with $\mathrm{ZrO}_{2}$ in the following percents: a) $5 \% \mathrm{ZrO}_{2}$, b) $10 \% \mathrm{ZrO}_{2}$, c) $15 \% \mathrm{ZrO}_{2}$, d) $20 \% \mathrm{ZrO}$. The morphology and structure of all compacts were determined using scanning electron microscope (SEM), EDS (quantitative and qualitative) and X-ray diffraction analysis (XRD). The microstructures differ in function of concentrations. XRD presents qualitative analysis of Co-Cr probes doped with zirconia and EDS analysis presents qualitative and quantitative analysis of composites compacts, before and after immersion in SBF for 21 days. After immersion in SBF, it can be noticed that the probes of $\mathrm{Co}-\mathrm{Cr}$ doped with zirconia demonstrate good corrosion resistance and that for the probe Co-Cr doped with $20 \%$ zirconia mechanical resistance is low. In this study the mechanical behavior of Co-Cr powder manufacturing by Direct Metal Laser Sintering (DMLS) process was determined. The sintering machine Phenix Systems type PXS \& PXM Dental uses the Co-Cr powder (ST2724G) and for 3D printing use "stl" file. The mechanical tests (traction and compression) was realized with an INSTRON 8810 machine.

Keywords: biodegradation; $\mathrm{Co}$-Cr sintered compact; dental implant; in vitro test; mechanical behaviour; $\mathrm{SEM}$ analysis; $\mathrm{ZrO} \mathrm{O}_{2}$; XRD analysis

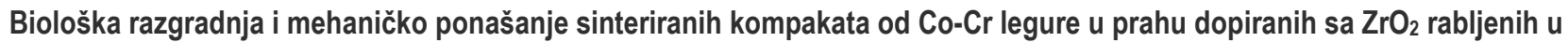
stomatologiji

Izvorni znanstveni članak

Direct Metal Laser Sintering je postupak moderne tehnologije s primjenom u različitim industrijama, uključujući medicinsku industriju. Namjena ovog istraživanja bila je dobiti sinterirane kompakte $\mathrm{Co}-\mathrm{Cr}$ praha dopiranog sa $\mathrm{ZrO}_{2}$ u cilju poboljšanja biološke aktivnosti implantata te ponašanja in vitro nakon uranjanja u simuliranu biološku tekućinu (SBF) tijekom 21 dana. Co-Cr prašak (ST2724G) rabljen je za izradu jednog referentnog uzorka Co-Cr i 4 kompakta Co-Cr dopirana sa $\mathrm{ZrO}_{2}$ u sljedećim postocima: a) $5 \% \mathrm{ZrO}_{2}$, b) $10 \% \mathrm{ZrO}_{2}$, c) $15 \% \mathrm{ZrO}_{2}$, d) $20 \% \mathrm{ZrO}$. Morfologija i struktura svih kompakta određena je skeniranjem elektronskim mikroskopom (SEM), EDS (kvantitativno i kvalitativno) i rendgenskom analizom difrakcije (XRD). Mikrostrukture se razlikuju u ovisnosti o koncentraciji. XRD predstavlja kvalitativnu analizu sondi Co-Cr dopiranih cirkonij-dioksidom i EDS analiza predstavlja kvalitativnu i kvantitativnu analizu kompozita kompakta, prije i nakon uranjanja u SBF tijekom 21 dana. Nakon uranjanja u SBF, može se primijetiti da su sonde Co-Cr dopirane s cirkonijem imale dobru otpornost na koroziju, a sonde Co-Cr dopirane s $20 \%$ cirkonija nizak mehanički otpor. U ovoj analizi je utvrđeno mehaničko ponašanje Co-Cr praha proizvedenog procesom izravnog laserskog sinteriranja metala (DMLS). Stroj za sinteriranje Phenix System tipa PXS \& PXM Dental koristio je Co-Cr prah (ST2724G) a za 3D ispis datoteku "stl". Ispitivanje mehaničkih svojstava (vlaka i kompresije) ostvareno je na INSTRON 8810 stroju.

Ključne riječi: biološka razgradnja; Co-Cr sinterirani kompakt; in vitro test; mehaničko ponašanje; SEM analiza; ZrO 2 ; zubni implantat; XRD analiza;

\section{Introduction}

The control and adaptation of the implant degradation rate are crucial, since the resorption capacity of the tissue is limited. Moreover, the local physiology of the implant environment determines the maximal degradation rate of a temporary implant.

There are many reasons that contribute to the corrosion of metals when implants are placed inside the human body. The existing in vitro corrosion test system always needs to be adapted to the corresponding in vivo application [1].

Permanent metallic implants can lead to certain biocompatibility problems related to continuous physical/mechanical irritation and long-term release of metallic ions and/or particles through corrosion or wear processes. The cast CoCrMo alloy was considered satisfactory for total hip replacements [2].

$\mathrm{Co}-\mathrm{Cr}$ alloys are generally known for their excellent wear resistance where they have been in use in dentistry for many decades and in making artificial joints [3].

$\mathrm{Co}-\mathrm{Cr}$ alloy powder used in DMLS manufacturing presents good sintering properties and grains of powder present spherical form necessary to obtain sintering probes [4]. The Co-Cr powder has grains of around 20 microns size $[5 \div 13]$. Direct metal laser sintering (DMLS) is a rapid prototyping technique and uses a laser as the power source and sinters the metallic powder material, aiming the laser automatically at points in space defined by a $3 \mathrm{D}$ model, binding the material together to create a solid structure. Co-Cr alloy presents good mechanical strength, good resistance to corrosion and a degree of cleaning identical to that of the glass $[14 \div 16]$. Powder of $\mathrm{Co}-\mathrm{Cr}$ alloy is considered tolerable in dentistry domain and is used for the realization of dental crowns, bridges and chapels. In the literature, no research has been made in vitro doping of Co-Cr alloy (ST2724G) with Zirconia in different percentages by mass.

Zirconia is a good ceramic bioactive material with excellent chemical and thermal resistance, toughness and mechanical strength. Deposition of $\mathrm{ZrO}_{2}$ thin films on stainless steel $316 \mathrm{~L}$ substrates by DC unbalanced magnetron sputtering leads to obtaining of $\mathrm{ZrO}_{2}$ with monoclinic phase and bioactivity in SBF [17].

Researches have demonstrated the importance of preparation and phase structure in development of properties as bioactivity of zirconia [18].

Similar research concerning the biodegradation behavior has been realized on Co-Cr alloy using a human cell culture model and showed a higher corrosion rate in the presence of osteoblasts in the range of $25 \div 30 \%$ [19]. 
Research concerning biodegradation in SBF was realized on magnesium by chromium and oxygen dual ion implantation showing that $\mathrm{Cr}$ is a passive element that can be optimized to control the degradation of pure magnesium [20].

DMLS process permits manufacturing different personalized medical implants, microsurgical medical instruments with complex geometry. This technique realized personalized pieces with a great precision and faster. Medical microsurgery instruments must present good mechanical resistance and good corrosion resistance. Co-Cr alloy powder is a superalloy powder and is a tolerable material in medicine domain.

The $\mathrm{Co}-\mathrm{Cr}$ powder presents good properties for sintering process, the grain size is very fine, $20 \mu \mathrm{m}$ and the grain form is spherical.

In this paper experimental researches concerning mechanical resistance (traction and compression) and corrosion resistance in artificial saliva Fusayama Meyer of $\mathrm{Co}-\mathrm{Cr}$ alloy samples have been carried out. The mechanical test realized on $\mathrm{Co}-\mathrm{Cr}$ superalloy samples, shows a very good mechanical and corrosion resistance.

Some authors have conducted studies concerning mechanical and corrosion resistance of metals used in medical domain, like titanium alloy Ti6Al4V, Ti-Ni alloys, stainless steel 304 or 316L and Co-Cr alloys. In literature are reported Rockwell hardness of dental alloys, $\mathrm{Co}-\mathrm{Cr}$ and $\mathrm{Ni}-\mathrm{Cr}[21,22]$.

\section{Materials and methods}

The compacts for dental implants with bioactive behavior in bone tissue were prepared starting from $\mathrm{Co}-\mathrm{Cr}$ powders (ST2724G) used for direct metal laser sintering (DMLS) process. Commercial powder of $\mathrm{ZrO}_{2}$ from Merck with a purity greater than $99 \%$ was used for doping.

$\mathrm{Co}-\mathrm{Cr}$ alloy used in this paper is of the following chemical composition: $\mathrm{Co} 54,31 \%$, $\mathrm{Cr} 23,08 \%$, Mo $11,12 \%$, W 7,85 \%, Si 3,35\% and $\mathrm{Mn}, \mathrm{Fe}<0,1$. The engineering properties of Co-Cr alloys (ST2724G) given by Phenix Systems [4] are:

elastic limit $\left.0,2 \% R p_{0,2}\right)=815 \mathrm{MPa}$

elongation at break $=10 \%$

Vickers hardness $=375$ HV 5

Elastic module $=229 \mathrm{GPa}$

Volume mass $=8,336 \mathrm{~g} / \mathrm{cm}^{3}$

Corrosion resistance $<4 \mu \mathrm{g} / \mathrm{cm}^{2}$

Thermal expansion coefficient $=14,5 \times 10^{-6} \mathrm{~K}^{-1}$.

\subsection{Co-Cr samples doped with Zirconia powder}

Different compositions were obtained starting from powder $\mathrm{Co}-\mathrm{Cr}$ and $5 \%, 10 \%, 15 \%, 20 \% \mathrm{ZrO}_{2}$ (percentage by mass). An undoped $\mathrm{Co}-\mathrm{Cr}$ sample was used as reference.The raw materials powders were homogenized for 30 minutes, in ethanol. The compacts were compacted by pressing into the mold to active section of $1 \mathrm{~cm}^{2}$. Compacts were realized using the pressures of $20 \mathrm{~kg} / \mathrm{cm}^{2}$.

The sinterization was made in an electrical furnace after a complex multistage regime. In the first stage of sintering the compacts were heated at a heating rate of 5
$\%$ min to $250{ }^{\circ} \mathrm{C}$ where a plateau of 10 minutes was maintained in order to remove water and organic residues, followed by the second stage of sintering at $700{ }^{\circ} \mathrm{C}$ for 30 minutes, using a heating rate of $10 \% \mathrm{~min}$. The compacts were cooled naturally up to ambient temperature.

The sintered composite compacts were investigated by SEM, EDS and XRD analysis. The bioactivity was realized by immersion of sintered composite compacts in SBF for 21 days. In this period, the sintered compacts suffer biodegradability in SBF, evidenced by SEM, EDS and XRD analysis.

Investigation of morphology and quantitative analysis of compacts were performed using scanning electron microscope QUANTA INSPECT F (qualitative and quantitative analysis) equipped with electron gun with field emission -FEG (field emission gun) with a resolution of 1,2 $\mathrm{nm}$ and $\mathrm{x}$-ray spectrometer for energy dispersive (EDS) with a resolution of $133 \mathrm{eV}$ at $\mathrm{MnK}$. For the chemical composition of the samples studied were used images of secondary electrons and backscatter electron images. The bright areas contain heavy elements (large atomic number) and the dark areas are light elements. The areas of interest were analysed qualitatively by micro compositional X-ray spectrometry.

XRD analysis was performed using an X-ray diffractometer that uses PAnalytical Empyrial characteristic $\mathrm{CuK} \alpha$ radiation and wavelength 1,541874 . Spectrum acquisition was performed in Bragg-Brentano geometry.

For mineralization assay, three compacts of each material were incubated in synthetic body fluid (SBF1x) at $p H=7,4$, adjusted with tris (hydroxy-methyl) aminomethane (Tris) and hydrochloric acid $(\mathrm{HCl})$, for 21 days, under sterile conditions, in containers with $45 \mathrm{~mL}$ of the incubation medium at $37{ }^{\circ} \mathrm{C}$. The incubation medium was changed every $48 \mathrm{~h}$. After incubation, the specimens were rinsed with distilled water to remove any traces of salts from the surface and dried at $40{ }^{\circ} \mathrm{C}$ for $24 \mathrm{~h}$. The composition of SBF1x is presented in Tab. 1 .

Table 1 Chemical composition of synthetic body fluid (SBF1x)

\begin{tabular}{|c|c|}
\hline Ionic composition & Concentration (mM) \\
\hline $\mathrm{Na}^{+}$ & 142,19 \\
\hline $\mathrm{Mg}^{2+}$ & 1,5 \\
\hline $\mathrm{Ca}^{2+}$ & 2,49 \\
\hline $\mathrm{HCO}_{3}{ }^{-}$ & 4,2 \\
\hline $\mathrm{Cl}^{-}$ & 141,54 \\
\hline $\mathrm{HPO}_{4}{ }^{2-}$ & 0,9 \\
\hline $\mathrm{SO}_{4}{ }^{2-}$ & 0,5 \\
\hline $\mathrm{K}^{+}$ & 4,85 \\
\hline
\end{tabular}

The presence of mineral crystals on the surface was evaluated by SEM analysis. The $\mathrm{Ca} / \mathrm{P}$ molar ratio was investigated by EDS spectroscopy. XRD patterns for mineralized compacts were obtained using a PAnalytical Empyrial diffractometer with $\mathrm{CuK} \alpha$ radiation.

\section{Results}

\subsection{Blind Co-Cr sintered compact}

SEM (Fig. 1) and XRD (Fig. 2) analysis was realized for $\mathrm{Co}-\mathrm{Cr}$ sintered composite as reference. The $\mathrm{Co}-\mathrm{Cr}$ compact contains spherical grains of around $20 \mu \mathrm{m}$. 
The great particles represent Co grains size and the smaller particles represent $\mathrm{Cr}$ grains size. The chemical composition was determinate by XRD and the result shows the single face of chromium cobalt molybdenum with chemical formula $\mathrm{Cr}_{0,32} \mathrm{Mo}_{0,04} \mathrm{Co}_{0,64}$ according to card 04-016-6870.

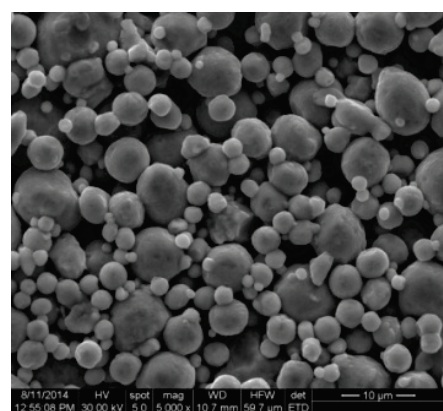

a) $(\times 5000)$

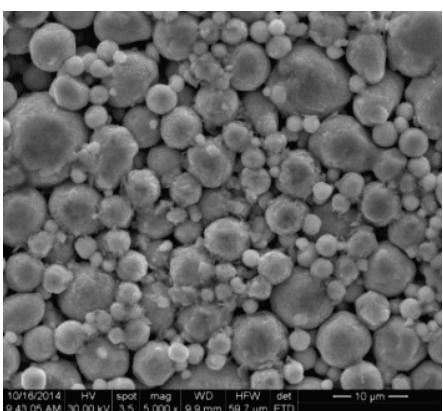

b) $(\times 5000)$

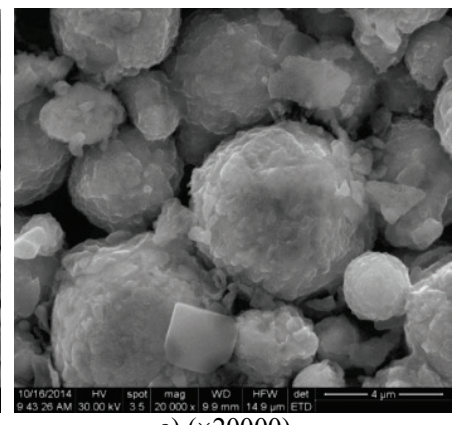

c) $(\times 20000)$

Figure 1 SEM images of the Co-Cr sintered compacts: a) before, b) and c) after immersion in SBF for 21 days

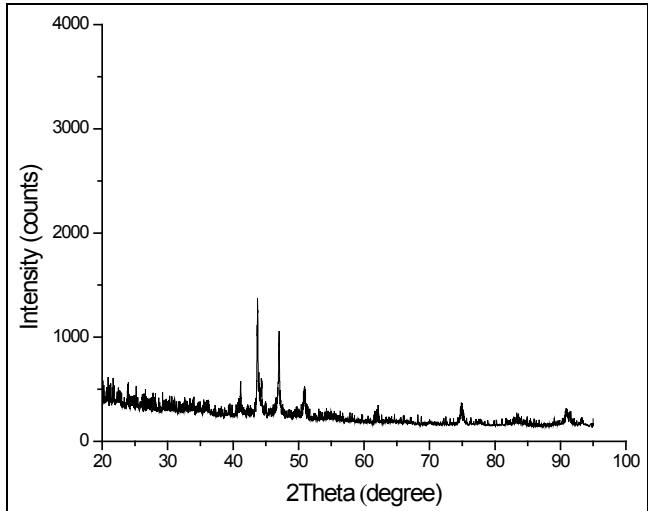

a)

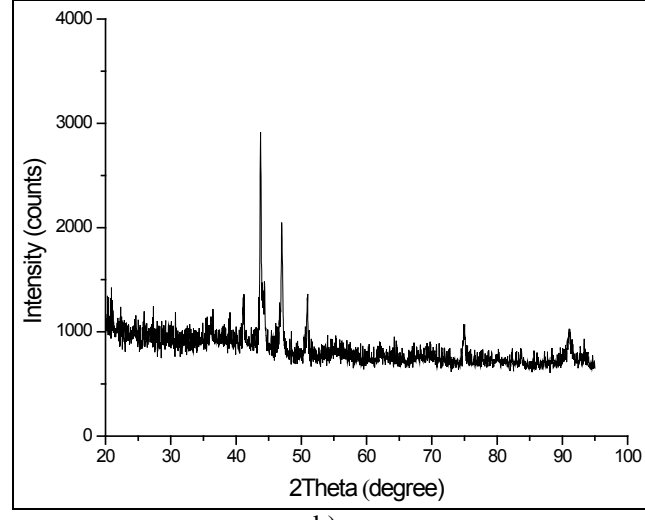

b)

Figure 2 XRD patterns of the Co-Cr sintered compacts: a) before and b) after immersion in SBF for 21 days

In order to increase bioactivity of compacts, they were immersed in simulated biological fluid during 21 days, then were dried and analyzed. Results of SEM and XRD show small corrosion effects on the particles as can be seen in Figs. 1b, 1c and $2 \mathrm{~b}$.

\subsection{Sintered compact of $\mathrm{Co}-\mathrm{Cr}$ doped with $5 \% \mathrm{wt} \mathrm{ZrO}_{2}$}

In Fig. 3 are presented SEM images of sintered compact of $\mathrm{Co}-\mathrm{Cr}$ doped with $5 \%$ wt $\mathrm{ZrO}_{2}$ at different magnifications. The compact sample of $\mathrm{Co}-\mathrm{Cr}$ doped with $5 \%$ wt $\mathrm{ZrO}_{2}$ shows a uniform and dense microstructure.

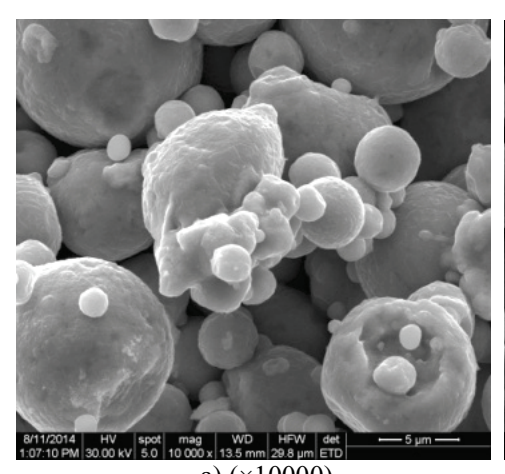

a) $(\times 10000)$

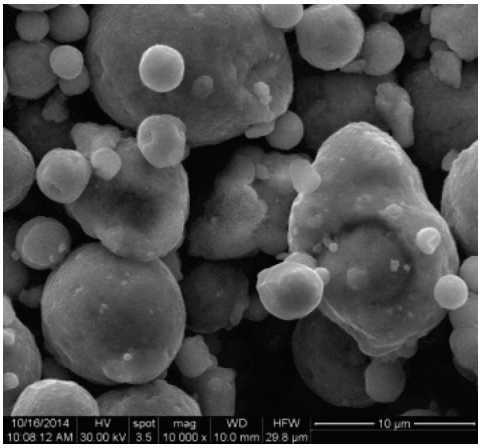

b) $(\times 10000)$

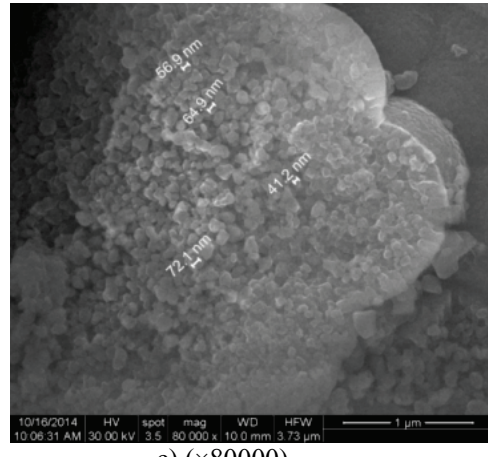

c) $(\times 80000)$

Figure 3 SEM images of sintered Co-Cr compacts doped with $5 \% \mathrm{wt} \mathrm{ZrO}_{2}$ : a) before, b) and c) after immersion in SBF for 21 days

Zirconia grains are of nanometrical scale with spherical grains. The compact shows a good compacting of grains that are not destroyed after immersion in SBF for 21 days (Fig. 3b and 3c). Some transformations of compact particles can be remarked. The compacts morphology shows some changes and damages; the particles are rounded to the existence of peeling particles like foils.

In Fig. 3b and 3c new areas of zirconia crystallites of nanometer sizes formed after immersion in SBF are distinguished. Some $\mathrm{ZrO}_{2}$ crystallites with size between $41 \div 71 \mathrm{~nm}$, are formed after immersion in SBF. Peaks of $\mathrm{Ca}$, or $\mathrm{P}$ do not stand out; no hydroxyapatite appeared. EDS analysis (Fig. 4) shows that the zirconia is uniformly dispersed in the compacted sample.

In Fig. 5 can be seen XRD pattern recorded on compact sintered sample of Co-Cr doped with $5 \% \mathrm{ZrO}_{2}$ and the result presents a body centered cubic crystalline structure. 

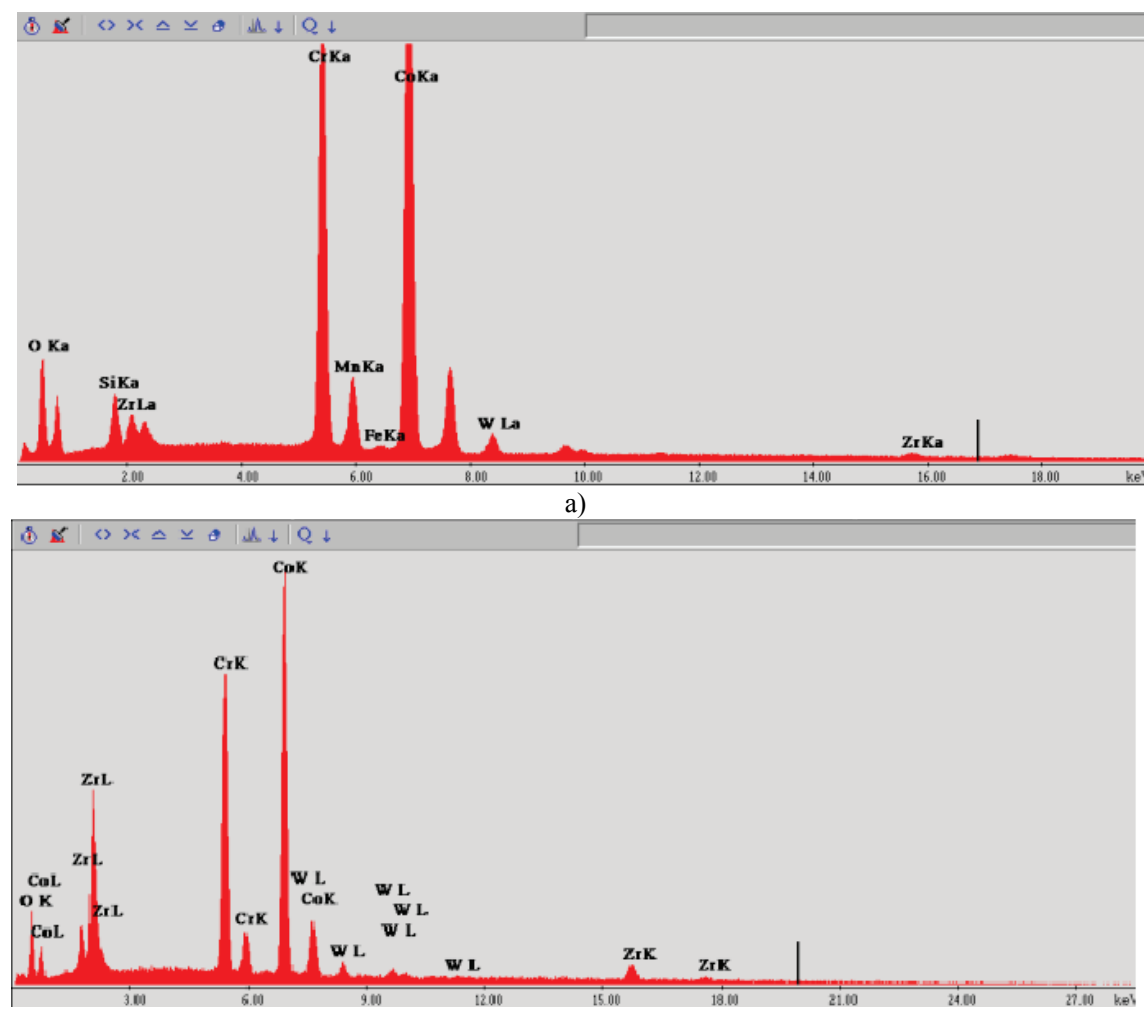

b)

Figure 4 EDS (quantitative and qualitative) analyses of sintered $\mathrm{Co}-\mathrm{Cr}$ compacts doped with $5 \% \mathrm{ZrO}_{2}$ : a) initially and b) after immersion in SBF for 21 days

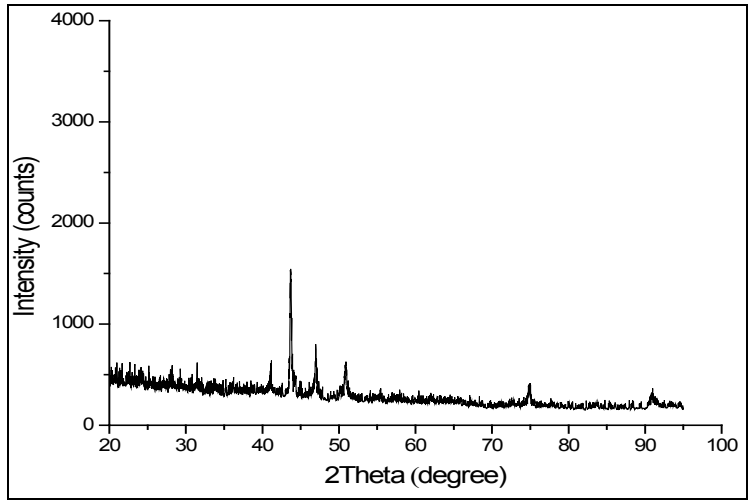

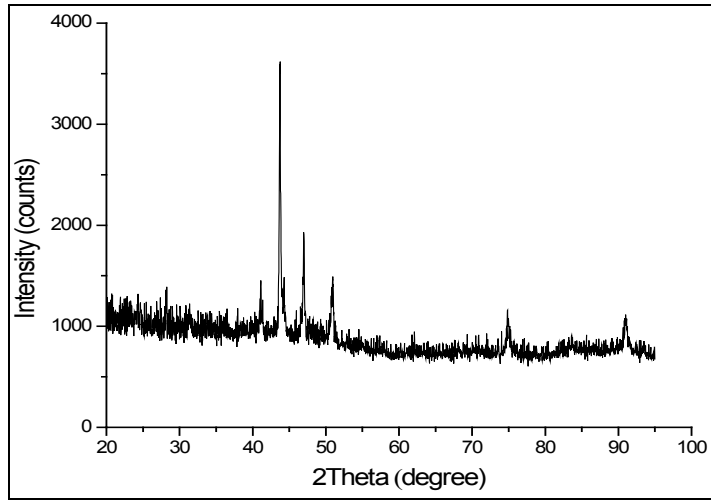

Figure $5 \mathrm{XRD}$ patterns of sintered compacts of $\mathrm{Co}-\mathrm{Cr}$ doped with $5 \% \mathrm{ZrO}_{2}$ : a) before and $\mathrm{b}$ ) after immersion in SBF for 21 days

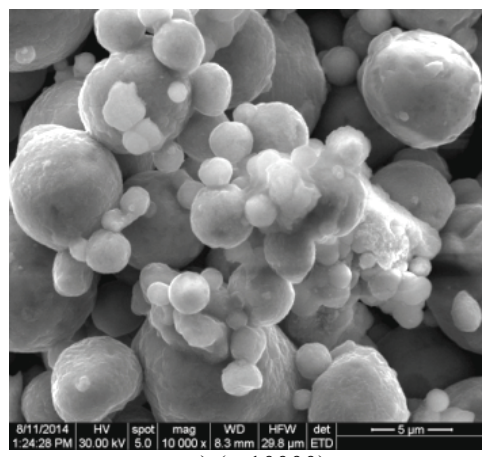

a) $(\times 10000)$

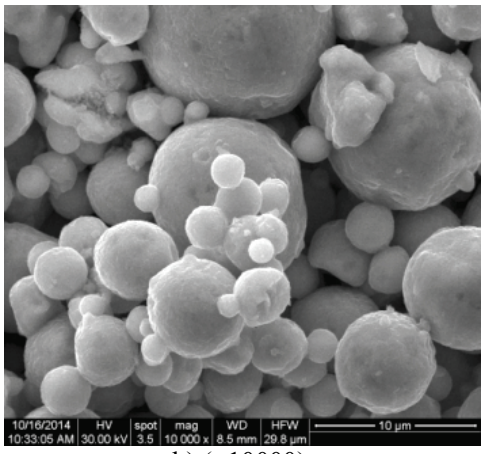

b) $(\times 10000)$

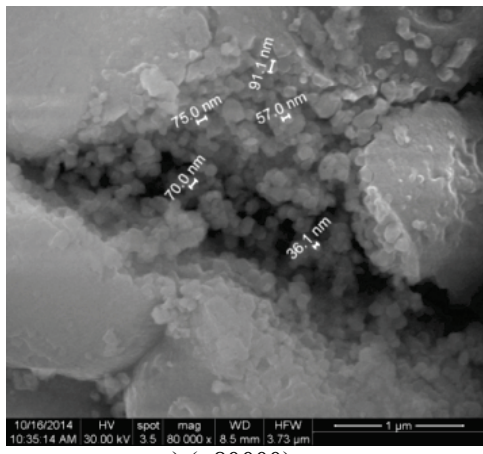

c) $(\times 80000)$

Figure 6 SEM images of sintered Co-Cr compacts doped with $10 \% \mathrm{ZrO}_{2}$ : a) before, b) and c) after immersion in SBF for 21 days

\subsection{Sintered compact of $\mathrm{Co}-\mathrm{Cr}$ doped with $10 \% \mathrm{wt} \mathrm{ZrO}_{2}$}

SEM images of Co-Cr compacts doped with $10 \% \mathrm{wt}$ $\mathrm{ZrO}_{2}$ are presented in Fig. 6 .

In the compact can be observed the uniform repartition of $\mathrm{Co}-\mathrm{Cr}$ and $\mathrm{ZrO}_{2}$ grains and the composition.
Zirconia is present as spherical grains with crystalline structure.

The sintered Co-Cr compact doped with $10 \% \mathrm{wt} \mathrm{ZrO}_{2}$ presents good compacting after immersion in SBF for 21 days (Fig. $6 \mathrm{~b}$ and 6c). SEM images show the effects of biodegradability on the sintered compact as degradation 
of particles. The particles become rounded with peeling like foils. After immersion in SBF new zones of zirconia crystallites of nanometer sizes can be determined.

In some zones, the micrometric particles of $\mathrm{ZrO}_{2}$ are transformed after immersion in SBF in nanometric crystallites. No hydroxyapatite was detected. EDS analysis (Fig. 7) shows the uniform distribution of $\mathrm{ZrO}_{2}$ in the sintered compact of $\mathrm{Co}-\mathrm{Cr}$ alloy before and after immersion in SBF. EDS analysis evidenced small tracks of $\mathrm{Ca}(<0,1 \%)$.

The peaks of $\mathrm{P}$ are not visible because of superposing after the bands of $\mathrm{Zr}$. In compact with $10 \% \mathrm{ZrO}_{2}$, the zones with $\mathrm{ZrO}_{2}$ crystallites there are more nanostructures than in the compact doped with $5 \% \mathrm{ZrO}_{2}$. In Fig. 8 the presence of zirconia $10 \% \mathrm{ZrO}_{2}$ in $\mathrm{Co}-\mathrm{Cr}$ composite compact was revealed by XRD analysis.
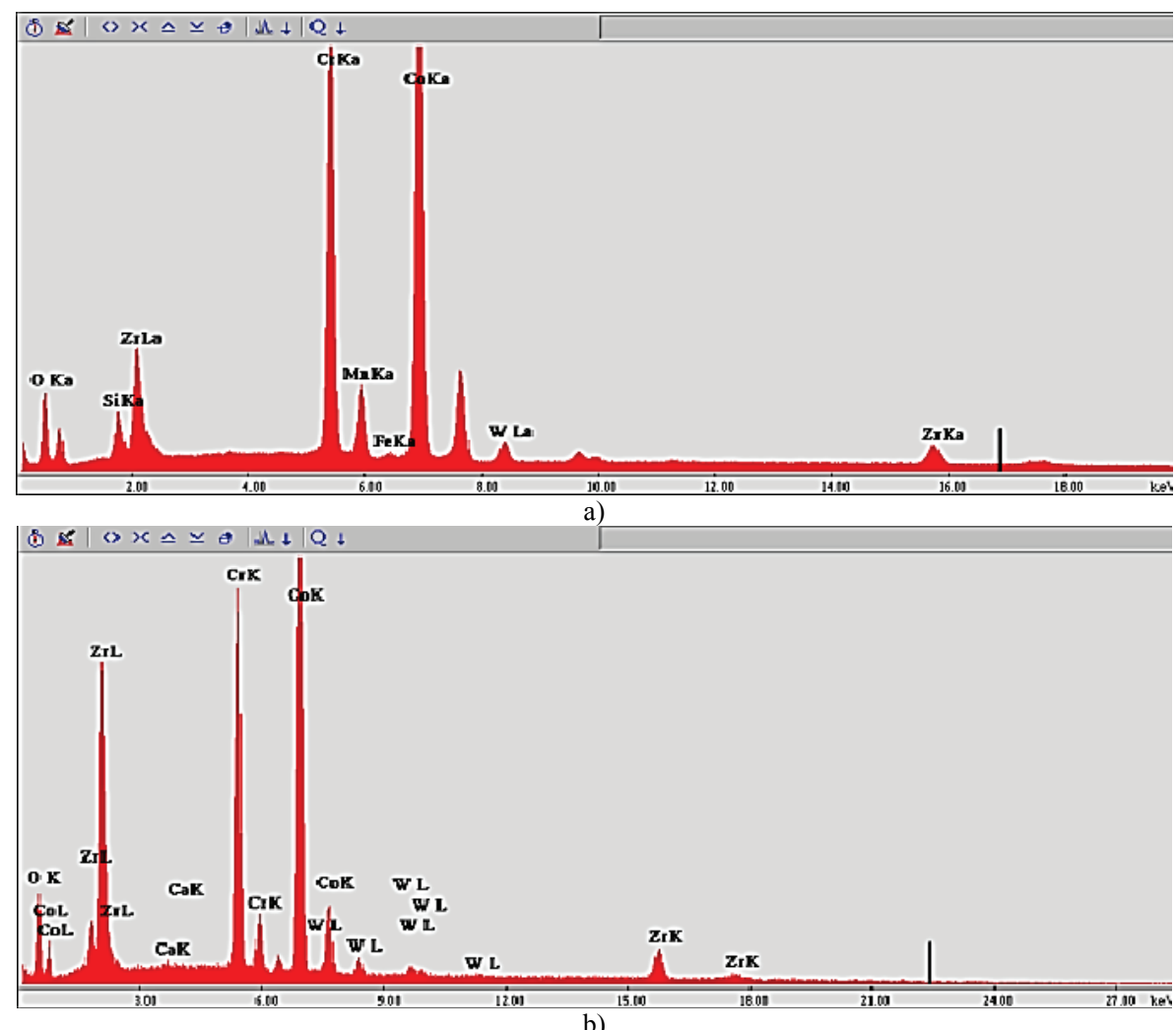

Figure $7 \mathrm{EDS}$ (quantitative and qualitative) analyses of sintered $\mathrm{Co}-\mathrm{Cr}$ compacts doped with $10 \% \mathrm{wt} \mathrm{ZrO}_{2}$ : a) initially and b) after immersion in SBF for 21 days

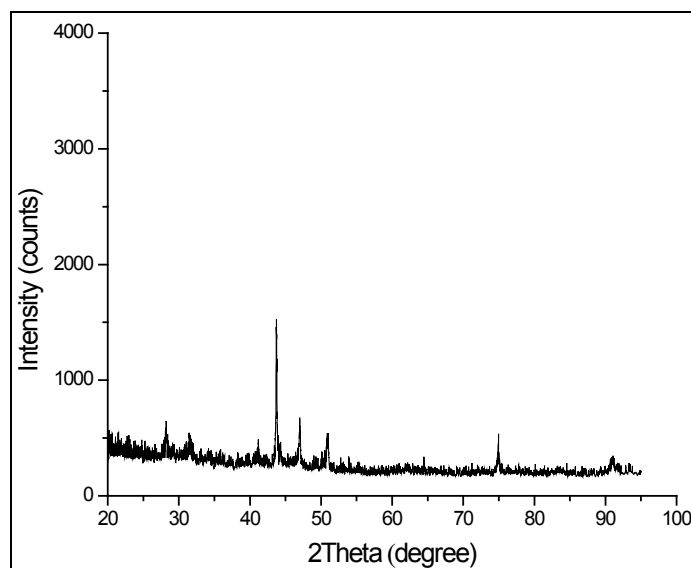

a)

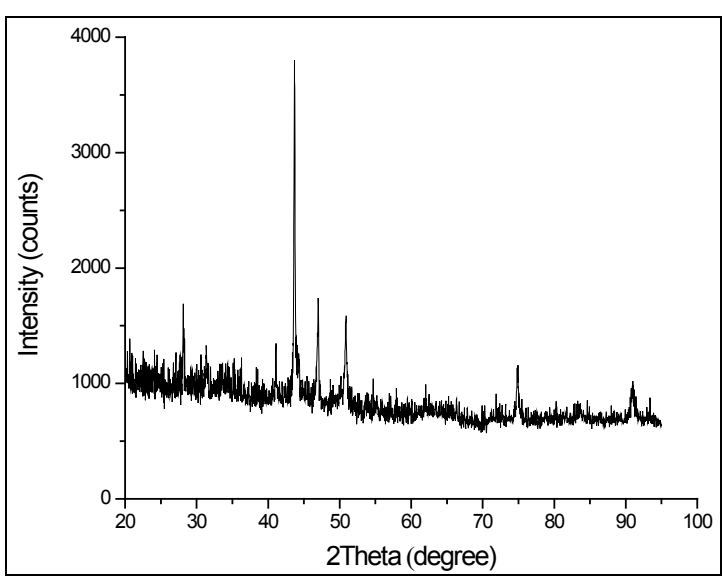

b)

Figure 8 XRD patterns of sintered compacts of Co-Cr doped with $10 \% \mathrm{wt} \mathrm{ZrO}_{2}$ : a) before and b) after immersion in $\mathrm{SBF}$ for 21 days

\subsection{Sintered compact of $\mathrm{Co}-\mathrm{Cr}$ doped with $15 \% \mathrm{wt} \mathrm{ZrO}_{2}$}

Fig. 9 reveals the microscopy SEM for compacts based on $\mathrm{Co}-\mathrm{Cr}$ doped with $15 \%$ wt $\mathrm{ZrO}_{2}$ with compact and uniform composition with a great quantity of $\mathrm{ZrO}_{2}$.

After immersion in SBF, some grains of $\mathrm{ZrO}_{2}$ are disolved and nanometer zirconia crystallites appear. The presence of zirconia in sintered compact and uniform dispersion can be spotted using EDS analysis. In EDS analysis the formation of small $\mathrm{Ca}$ and $\mathrm{P}$ peaks can be observed in Fig. 10.

After immersion in SBF for 21 days, hydroxyapatite formation is possible in very small quantity $(<0,1 \%)$, due to zirconia bioactivity. In Fig. $9(\times 1000)$ the large spherical particles are Co particles, the medium ones are $\mathrm{Cr}$ particles and the small ones are spherical zirconia. 
The amount of $15 \% \mathrm{ZrO}_{2}$ was determined using XRD analysis, like in Fig. 11. The hydroxyapatite amount was not determined by XRD analysis, after immersion of sintered compact in SBF.

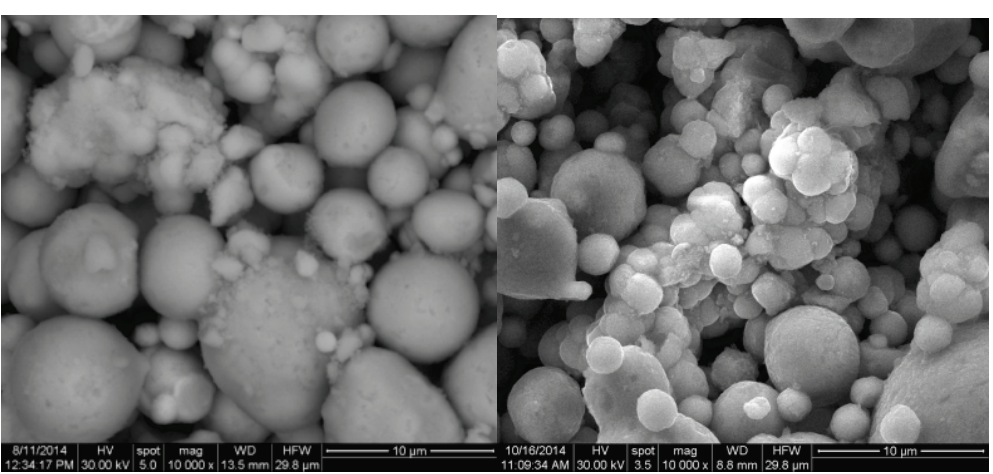

a) $(\times 10000)$

b) $(\times 10000)$

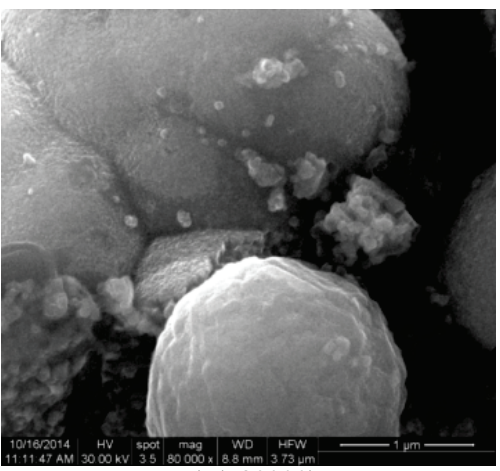

c) $(\times 80000)$

Figure 9 SEM images of sintered compacts Co-Cr doped with $15 \% \mathrm{ZrO}_{2}$ : a) before and b-c) after immersion in SBF for 21 days
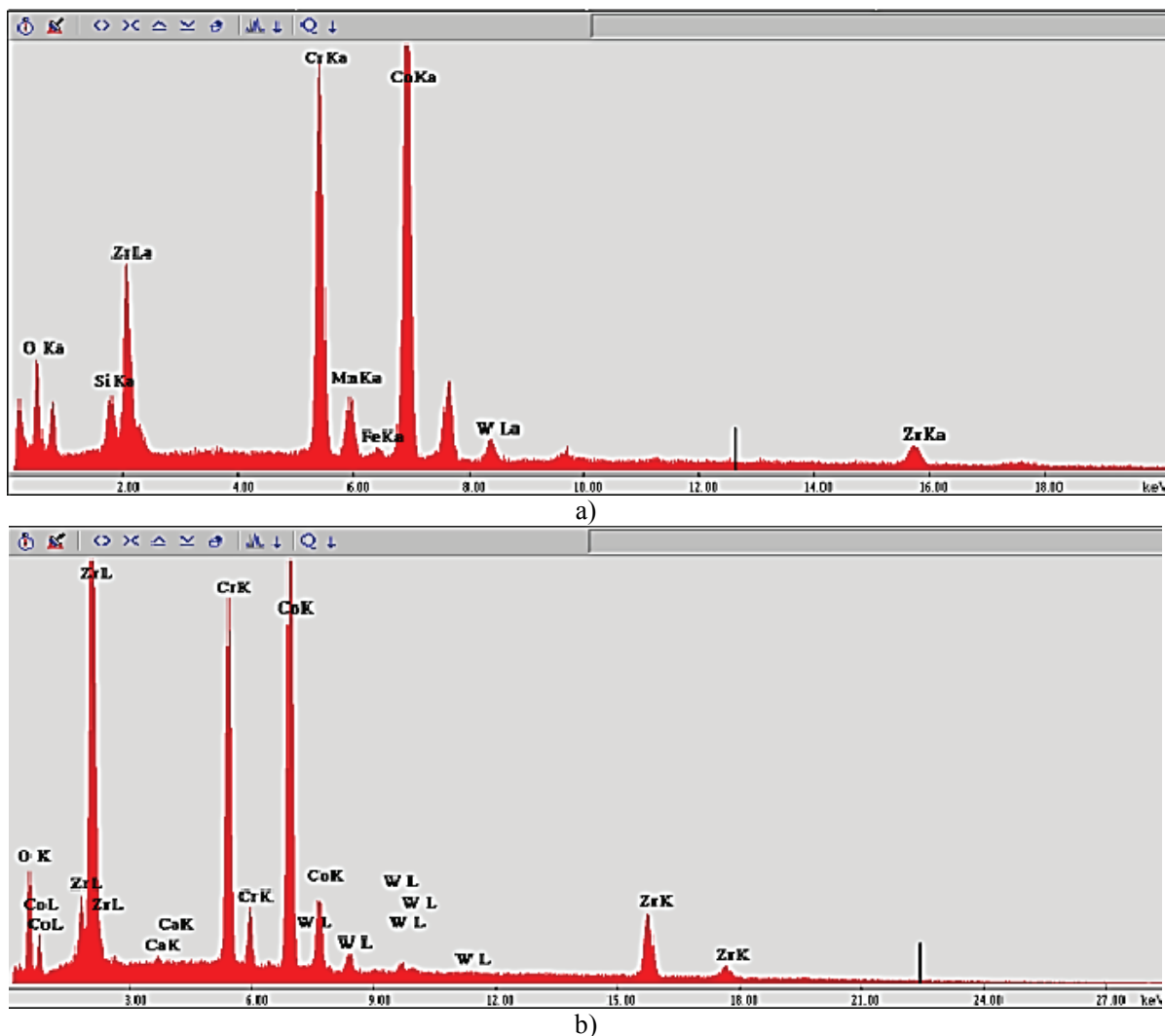

Figure 10 EDS (quantitative and qualitative) analyses of sintered compacts of Co-Cr doped with $15 \%$ $\mathrm{ZrO}_{2}$ : a) initially and b) after immersion in SBF for 21 days

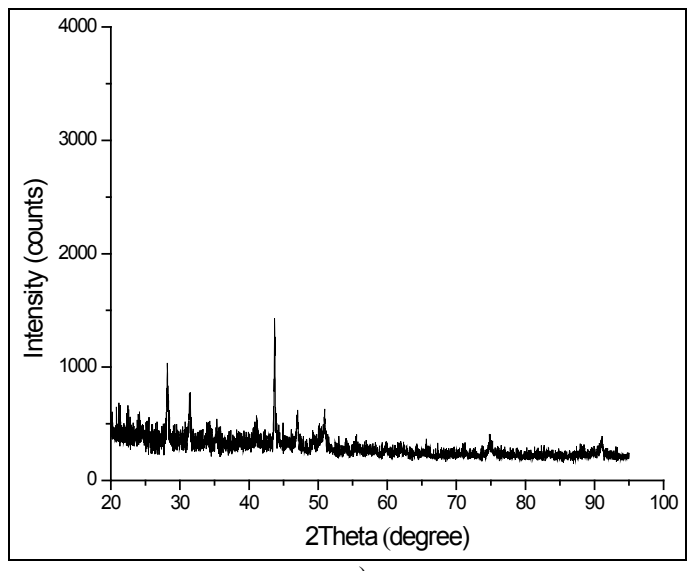

a)

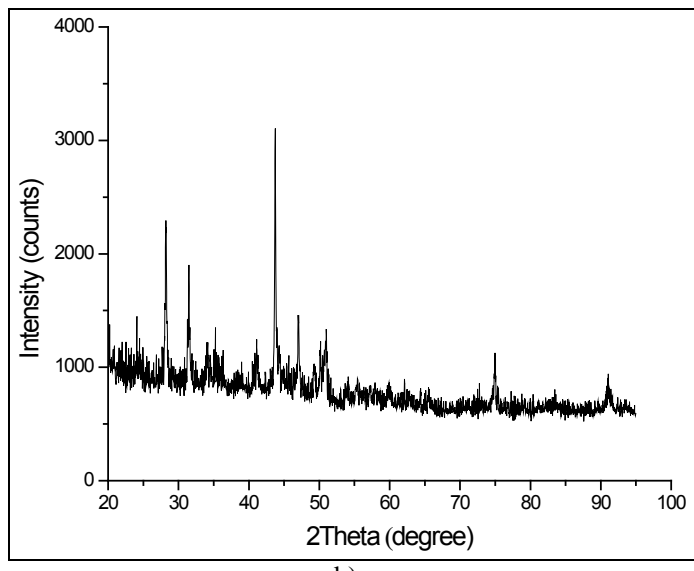

b)

Figure $11 \mathrm{XRD}$ patterns of sintered compacts of $\mathrm{Co}-\mathrm{Cr}$ doped with $15 \% \mathrm{ZrO}_{2}$ : a) before and b) after immersion in SBF for 21 days 


\subsection{Sintered compact of $\mathrm{Co}-\mathrm{Cr}$ doped with $20 \% \mathrm{wt} \mathrm{ZrO}_{2}$}

SEM microscopy of the sintered compacts of $\mathrm{Co}-\mathrm{Cr}$ doped with $20 \%$ wt $\mathrm{ZrO}_{2}$ is presented in Fig. 12 .
The quantity of zirconia is very big and the dispersion is uniform. The small spherical grains are of $\mathrm{ZrO}_{2}$. After immersion in SBF during 21 days, in SEM image appear areas of very fines crystallites of $\mathrm{ZrO}_{2}$ with size $31 \div 41$ $\mathrm{nm}$.

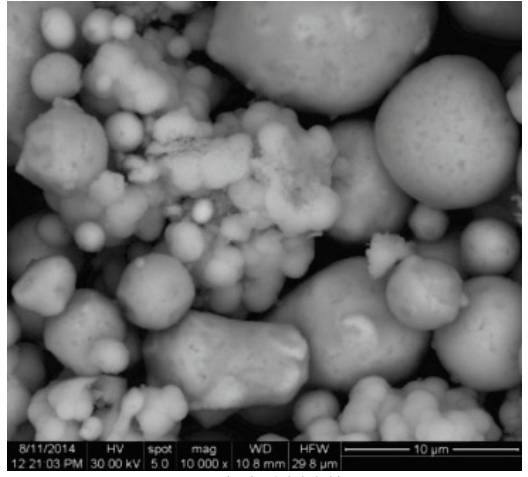

a) $(\times 10000)$

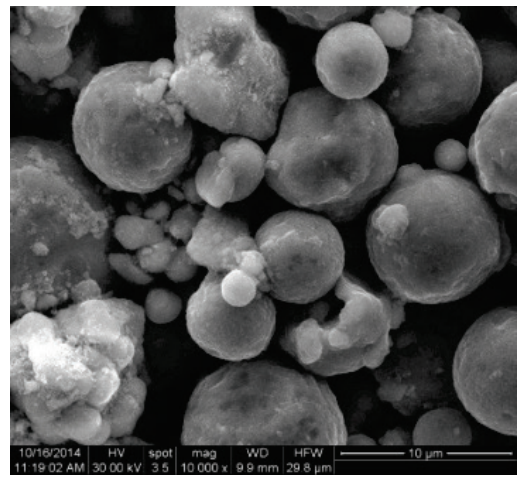

b) $(\times 10000)$

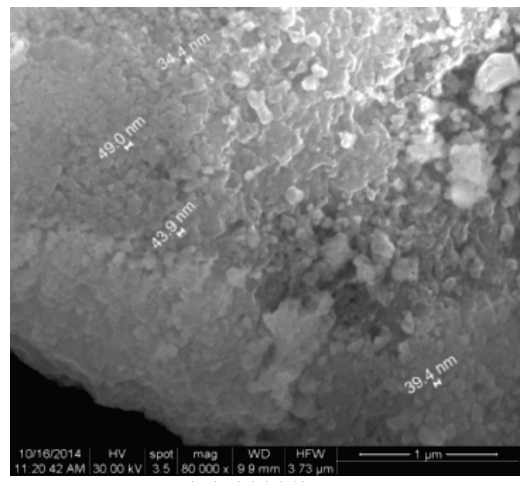

c) $(\times 80000)$

Figure 12 SEM images of sintered compacts of Co-Cr doped with $20 \% \mathrm{wt} \mathrm{ZrO}_{2}$ : a) before, b) and c) after immersion in SBF for 21 days
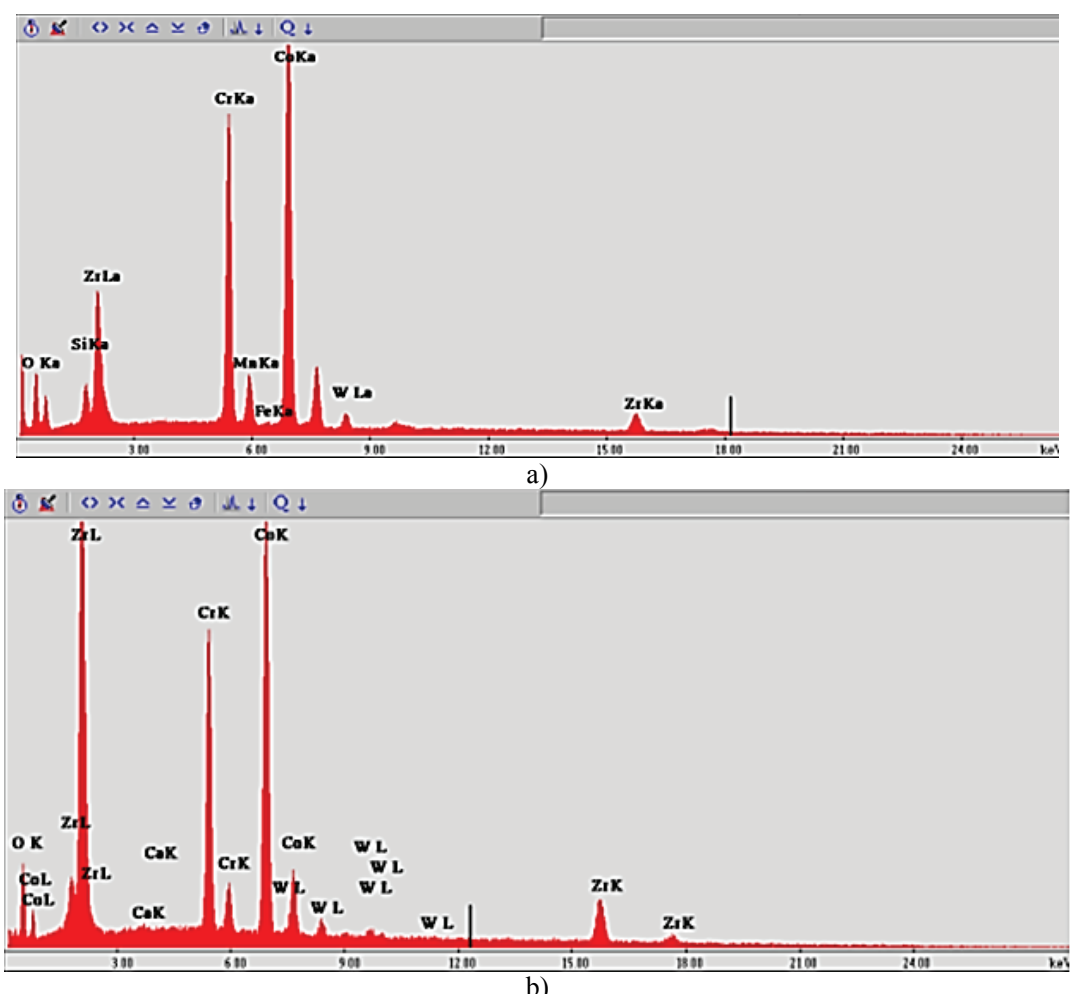

Figure 13 EDS (quantitative and qualitative) analyses of sintered compacts of Co-Cr doped with $20 \%$ wt $\mathrm{ZrO}_{2}$ : a) initially and b) after immersion in SBF for 21 days

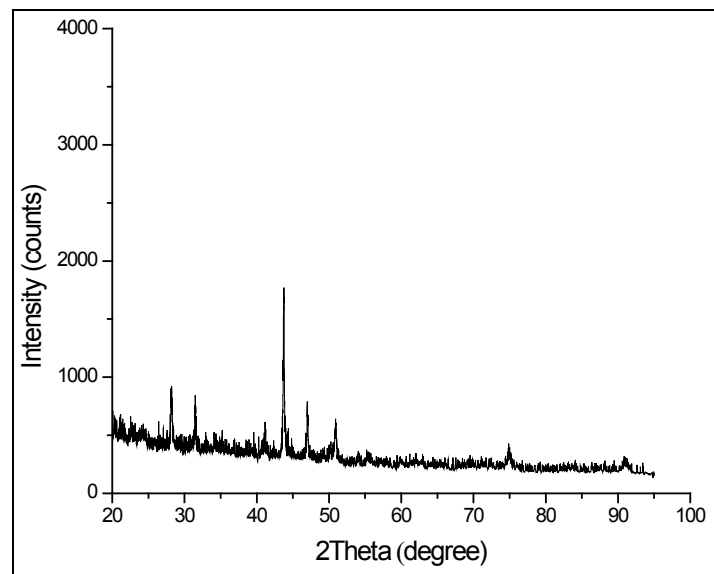

a)

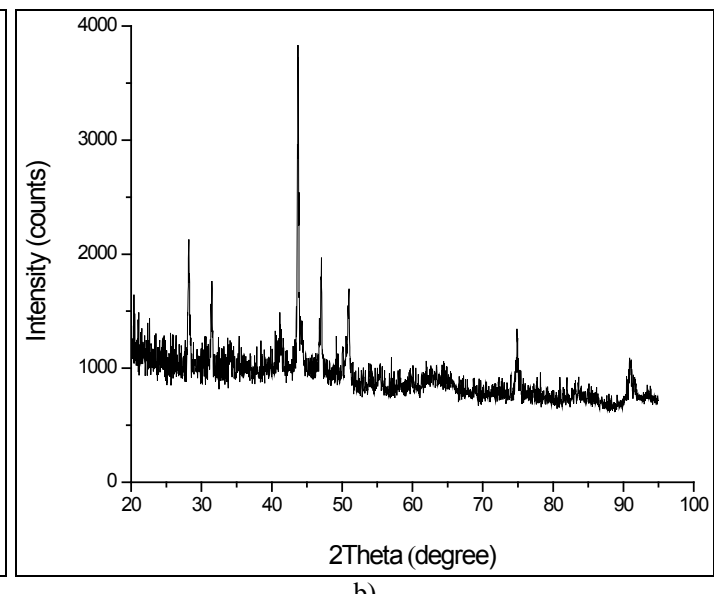

b)

Figure $14 \mathrm{XRD}$ patterns of sintered compacts of $\mathrm{Co}-\mathrm{Cr}$ doped with $20 \% \mathrm{ZrO}_{2}$ : a) before and b) after immersion in $\mathrm{SBF}$ for $21 \mathrm{days}$ 
EDS mapping in Fig. 13a shows that the big spherical grains are assigned to $\mathrm{Co}-\mathrm{Cr}$ and the small ones to $\mathrm{ZrO}_{2}$ alloy.

Fig. 12b presents the compact after immersion in SBF for 21 days. The EDS spectrum shows low peaks for $\mathrm{Ca}$ (approximate $1 \%$ ) and the mapping shows the formation of a thin film of hydroxyapatite on the surface of the grains of compact.

If the maps of $\mathrm{Ca}, \mathrm{Co}, \mathrm{Cr}$ and $\mathrm{Zr}$ are compared one can remark the presence of the hydroxyapatite everywhere on the $\mathrm{ZrO}_{2}$ grains and on the Co-Cr grains.

EDS analysis shows the presence of Ca peaks, in very small quantity. The $\mathrm{P}$ peaks are not visible because of the bands of $\mathrm{Zr}$ that are overlapping on the $\mathrm{P}$ bands.

This observation can be explained by possible formation of bonds $\mathrm{Co}-\mathrm{O}-\mathrm{Zr}$ and $\mathrm{Cr}-\mathrm{O}-\mathrm{Zr}$ in initial compact during the sinterization. In figure 14 are presented XRD patterns of compact doped with $20 \%$ $\mathrm{ZrO}_{2}$.

Note that after immersion in SBF the compacts doped with high concentration of zirconia give them poor mechanical properties because they are brittle. It is optimal to recommend using $\mathrm{Co}-\mathrm{Cr}$ sintered compacts doped with $5 \%$ to $10 \% \mathrm{ZrO}_{2}$.

Co-Cr sintered compact doped with $5 \% \mathrm{ZrO}_{2}$, after SBF immersion during 21 days, presents a biodegradation, evidenced by SEM analysis. The Co-Cr grains are more rounded with fine degradation foils. After immersion of Co-Cr sintered compact with $5 \% \mathrm{ZrO}_{2}$ in SBF, zones appear with fine crystallites of $\mathrm{ZrO}_{2}$ of nanometric size between 41-71 nm.

For sintered compact of Co-Cr with $10 \% \mathrm{ZrO}_{2}$, after SBF immersion, Co-Cr grains suffer biodegradation and zones with finer zirconia crystallites appear comparing with the compact doped with $5 \% \mathrm{ZrO}_{2}$, as can be seen in SEM.

The size of crystallites is between $36 \div 75 \mathrm{~nm}$. EDS analysis shows the presence of Ca peaks in small quantity $(<0,1 \%)$. Due to bioactive behavior of $\mathrm{ZrO}_{2}$ hydroxyapatite can appear in compacts.

In the case of the $\mathrm{Co}-\mathrm{Cr}$ sintered compact with $15 \%$ $\mathrm{ZrO}_{2}$ the degradation of compact was observed after immersion in SBF during 21 days.

EDS analysis determines Ca peaks in small quantity $(<0,1 \%)$. The quantity of $\mathrm{ZrO}_{2}$ in sintered compacts is determined by XRD analysis.

After immersion in SBF for 21 days, the sintered Co$\mathrm{Cr}$ compact doped with $20 \% \mathrm{ZrO}_{2}$ presents some transformation and biodegradation of $\mathrm{Co}-\mathrm{Cr}$ grains with rounded shape and zones with very fine nanometric zirconia crystallites of $36 \div 41 \mathrm{~nm}$ size. Remark the presence of Ca peaks in small quantity (approximately 0,1 $\%$, by EDS analysis.

XRD analysis shows the presence of $\mathrm{ZrO}_{2}$ in sintered compact $(20 \%)$.

\section{Mechanical tests of sintered powder of $\mathrm{Co}-\mathrm{Cr}$ (ST2724G) by DMLS process}

Six samples of Co-Cr (ST2724G), dental alloy manufactured by DMLS process were evaluated concerning mechanical properties, three samples for traction test and the other three samples for compression test.

The samples are projected by SolidWorks soft and save like "stl" file.

The samples are sintered using Phenix Systems machine type PXS \& PXM Dental, the fiber laser $(P=50$ $\mathrm{W}, \lambda=1070 \mathrm{~nm})$, manufactured volume is $100 \times 100 \times 80$ $\mathrm{mm}$, machine dimensions are $L=1,20 \mathrm{~m} ; l=0,77 \mathrm{~m} ; H=$ $1,95 \mathrm{~m}$. Machine soft used is Phenix Dental. The sintering temperature is $1300{ }^{\circ} \mathrm{C}$. The nitrogen gas is used for the process

\subsection{SolidWorks designing and DMLS manufacturing}

The pieces necessary for research were designed by SolidWorks 2010 software. In figure 15 was designed the piece necessary for traction test and in figure 16 was designed the piece necessary for compression test.

The pieces design is realized like "sldprt" file and saved like "stl" to be viewed by computer of Phenix System PXS \& PXM Dental machine.

The pieces are manufactured using Phenix System PXS \& PXM Dental machine, by DMLS process.

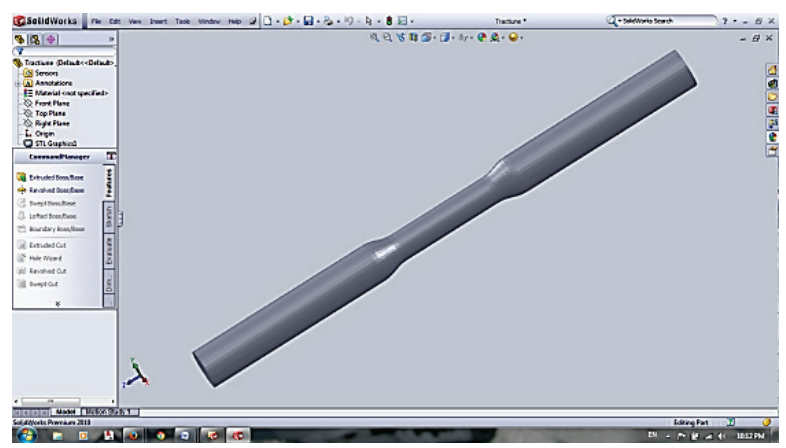

Figure 15 "stl" file of traction sample projected on SolidWorks

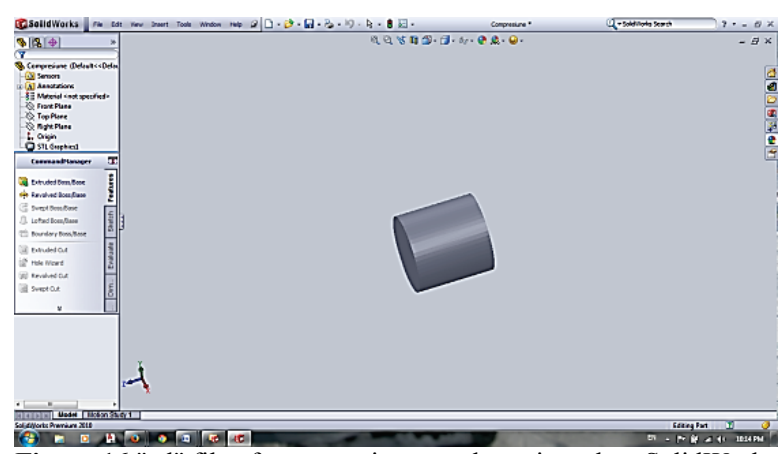

Figure 16 "stl" file of compression sample projected on SolidWorks

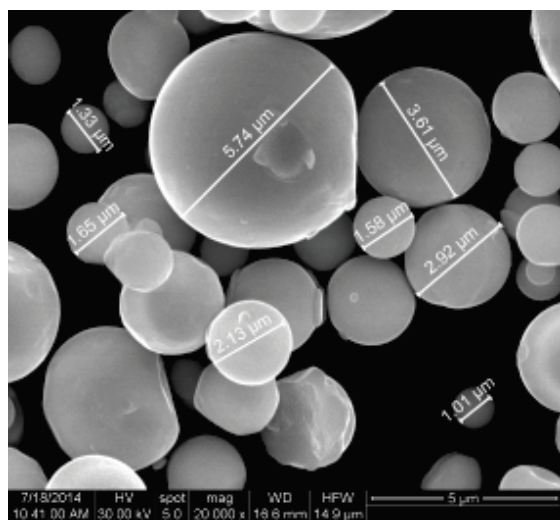

Figure 17 SEM analysis of Co-Cr alloy powder $(\times 20000)$ 
The SEM analysis of Co-Cr powder used by DMLS process is presented in Fig. 17 and the sintered pieces present the structure morphology like in Fir. 18.

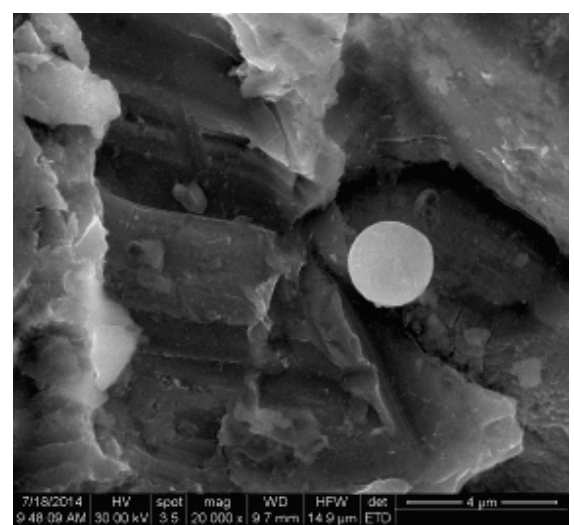

Figure $18 \mathrm{SEM}$ analysis of sintered probe of Co-Cr alloy powder $(\times 20000)$

It can be seen from Fig. 17 that the $\mathrm{Co}-\mathrm{Cr}$ alloy powder is very fine with spherical form of grain and grain size of around $20 \mu \mathrm{m}$. The sinterization process DMLS used a laser with power of $50 \mathrm{~W}$, the temperature of sinterization varied between $1300{ }^{\circ} \mathrm{C} \div 1600{ }^{\circ} \mathrm{C}$, the powder layer was approximately $20 \mu \mathrm{m}$.

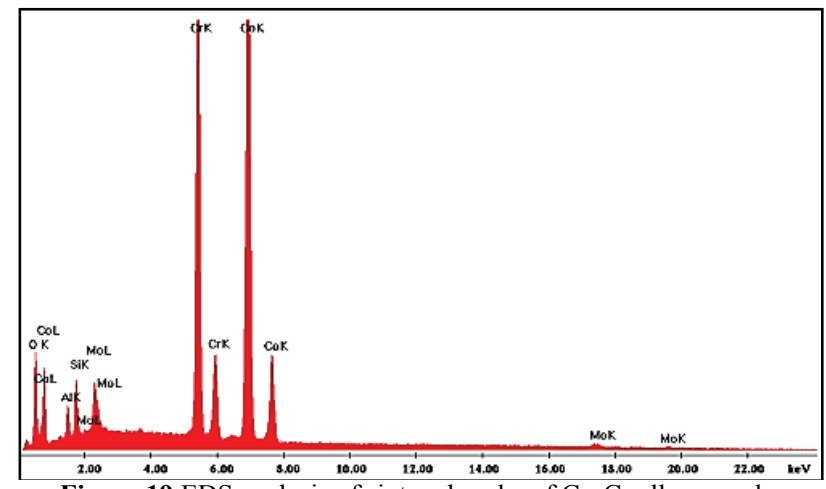

Figure 19 EDS analysis of sintered probe of $\mathrm{Co}-\mathrm{Cr}$ alloy powder
The SEM analysis of sintered piece shows a porous material, like in Fig. 18. EDS analysis realized for the sintered piece shows the composition of Co-Cr alloy. After sinterization by DMLS process, the material shows great purity, like in the EDS analysis, Fig. 19.

\subsection{Mechanical tests - Traction test}

Diameter of the traction sample is $5 \mathrm{~mm}$ in the center and $7 \mathrm{~mm}$ at the ends of sample. The length of the sample is $10 \mathrm{~mm}$. The samples manufactured by DMLS present great precision and good mechanical properties. In Fig. 20 is presented the traction test on INSTRON 8810 machine using cross head speed of $0,5 \mathrm{~mm} / \mathrm{min} .3$ samples were subjected to traction test.

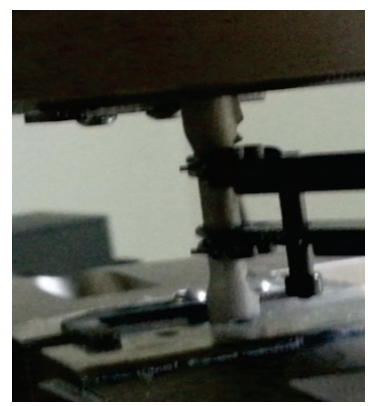

a)

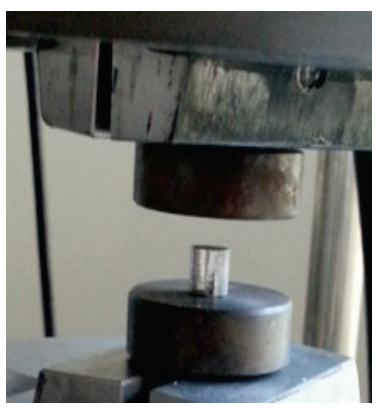

b)
Figure 20 Traction test a) and compression test b) of Co-Cr alloy sample

In Tab. 2 are presented the values obtained after traction test of sintered sample of Co-Cr alloy by DMLS process. Good tensile of the sintered samples obtained by DMLS process can be noticed. The maximal tensile strength is around $1200 \mathrm{MPa}$.

Samples break suddenly perpendicular to the axis, around tensile strength of $1200 \mathrm{MPa}$ and the strong fragile mechanical behavior can be observed. The morphological structure of Co-Cr alloy, after the traction test, was obtained by SEM analysis, like in Fig. 21.

Table 2 Traction strength of sintered samples of Co-Cr alloy by DMLS process

\begin{tabular}{|c|c|c|c|c|c|}
\hline $\begin{array}{l}\mathrm{Nb} . \\
\text { probe }\end{array}$ & $\begin{array}{l}\text { Modulus (Segment } 0,01 \\
\% \div 0,1 \%)(\mathrm{MPa})\end{array}$ & $\begin{array}{c}\text { Tensile stress at Tensile } \\
\text { Strength }(\mathrm{MPa})\end{array}$ & $\begin{array}{c}\text { Tensile strain at Tensile } \\
\text { Strength }(\%)\end{array}$ & Diameter (mm) & $\begin{array}{l}\text { Tensile stress at Yield } \\
(\text { Offset } 0,2 \%)(\mathrm{MPa})\end{array}$ \\
\hline 1 & 215070,31036 & 1199,20208 & 10,53235 & 4,92000 & 938,26940 \\
\hline 2 & 220511,41664 & 1191,53786 & 11,52003 & 4,92000 & 841,89392 \\
\hline 3 & 217965,73120 & 1197,37192 & 11,38575 & 4,92000 & 933,14574 \\
\hline
\end{tabular}

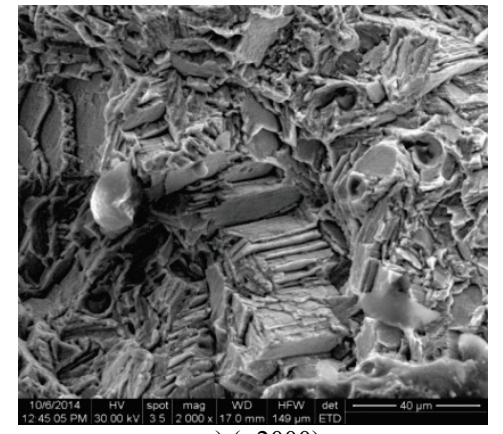

a) $(\times 2000)$

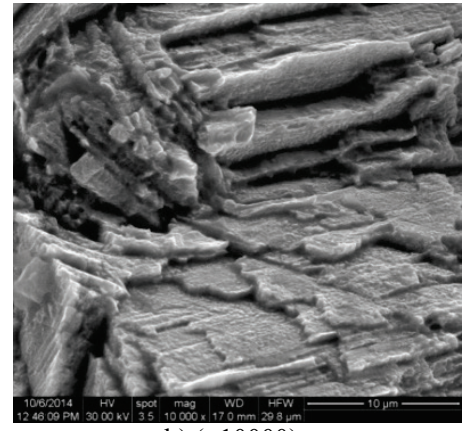

b) $(\times 10000)$

Figure 21 SEM analysis of traction test of sintered samples of $\mathrm{Co}-\mathrm{Cr}$ alloy 

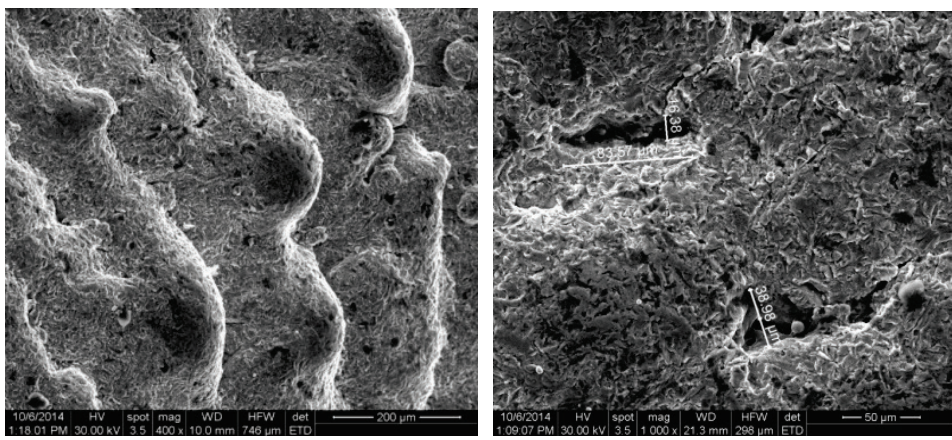

Figure 22 SEM analysis of compression test of sintered samples of Co-Cr alloy

After traction tests the material deformation, flattened pores, regular layers can be observed and the cracking is perpendicular on sample.

\subsection{Mechanical tests - Compression test}

The compression samples are manufactured by DMLS and present great precision and good mechanical properties. Diameter of the compression sample is $7 \mathrm{~mm}$ in center and the length is $7 \mathrm{~mm}$.

In Tab. 3 are presented the values obtained after compression test of sintered samples of $\mathrm{Co}-\mathrm{Cr}$ alloy manufactured by DMLS process. The results show a good compression resistance and the maximal tensile is around $1200 \mathrm{MPa}$.

Table 3 Compressive strength of sintered sample of Co-Cr alloy by DMLS process

\begin{tabular}{|c|c|c|}
\hline Nb. probe & $\begin{array}{c}\text { Compressive stress at } \\
\text { Tensile Strength }(\mathrm{MPa})\end{array}$ & $\begin{array}{c}\text { Modulus (Segment 2\% } \\
\div 3 \%)(\mathrm{MPa})\end{array}$ \\
\hline 1 & 1791,62067 & 10495,54594 \\
\hline 2 & 1821,92217 & 15905,64368 \\
\hline 3 & 1822,51273 & 15757,25712 \\
\hline
\end{tabular}

SEM analysis presented in Fig. 22 shows the behavior at compression at $20{ }^{\circ} \mathrm{C}$ for $\mathrm{Co}-\mathrm{Cr}$ sintered compacts. The samples present strong fragile mechanical behavior. The material deformation, flattened pores of 16 $\mu \mathrm{m}$ can be remarked. Strain hardening and some fine fissures are present in the material.

\section{Conclusions}

In this paper, sintered compacts on the basis of the Co-Cr-doped with $5 \%, 10 \%, 15 \%, 20 \%$ by mass of $\mathrm{ZrO}_{2}$ were obtained in order to use them for implants. Zirconia present a bioactive behavior and can increase the bioactivity of implants. The sintering treatment of Co-Cr compacts doped with $\mathrm{ZrO}_{2}$ at $700{ }^{\circ} \mathrm{C}$ determines a dense structure of compacts with uniform distribution of grains of $\mathrm{Co}, \mathrm{Cr}$ and $\mathrm{ZrO}_{2}$. SEM and EDS show high homogeneity of $\mathrm{ZrO}_{2}$ in all compacts regardless of the amount used for doping. XRD analysis determines the presence of $\mathrm{ZrO}_{2}$ in sintered compacts. The sintered compacts were immersed in SBF during 21 days, to determine the biodegradation behavior of $\mathrm{Co}-\mathrm{Cr}$ compacts doped with different concentration of $\mathrm{ZrO}_{2}$.

In case of the sintered compacts $\mathrm{Co}-\mathrm{Cr}$ doped with different concentration of $\mathrm{ZrO}_{2}$ a good corrosion resistance in SBF was remarked.
After immersion in SBF, all sintered Co-Cr compacts doped with $\mathrm{ZrO}_{2}$ present biodegradation, with grains that have rounded shape with some foils, determined by SEM analysis. The zirconia micrometric size is transformed after SBF immersion in nanostructure size. Zones with nanometric grains of $\mathrm{ZrO}_{2}$ appear. For the sintered compacts with $10 \%, 15 \%, 20 \% \mathrm{ZrO}_{2}$, EDS analysis shows the presence of $\mathrm{Ca}$ peaks in small quantity $(<0,1 \%)$. Due to bioactive behavior of $\mathrm{ZrO}_{2}$ hydroxyapatite can appear in compacts. The quantity is very small and is shown only by EDS analysis.

Concerning the mechanical properties, the sintered Co- $\mathrm{Cr}$ compacts doped with $10 \%$ and $15 \% \mathrm{ZrO}_{2}$ are optimal to be used for dental implants manufacturing.

The sintered pieces obtained by DMLS manufacturing show very good mechanical properties and have fragile strength characteristics, because of porous structure specific to sintered pieces. The sintered samples show tensile resistance to traction of approximately 1200 $\mathrm{MPa}$. During the compression tests, the sintered samples are damaged to the compression tensile at $1200 \mathrm{MPa}$. The mechanical resistance is satisfactory for a microsurgery instrument. The microstructure shows a deformation structure with flattened pores and some fine fissures.

\section{Acknowledgements}

This work is supported by the Sectorial Operational Programme Human Resources Development (SOP HRD), financed from the European Social Fund and the Romanian Government, under the contract number POSDRU/159/1.5/S/138963 - PERFORM.

\section{References}

[1] Eliaz, N. Degradation of implants materials, Ed. Springer, 2012.

[2] Djokic, S. S., Biomedical applications, Ed. Springer, 2012.

[3] Hermawan, H. Biodegradable metals - From Concept to applications, Ed. Springer, 2012.

[4] http://www.phenix-systems.com/en/materials.

[5] Berce, P.; Ancau, M.; Balc, N.; Caizer, C.; Comsa, S.; Chezan H. Rapid Prototyping Manufacturing. // Tehnical Publishing, Bucharest 2000.

[6] Schatt, W.; Wieters, K. P. Powder Metallurgy. // Processing and materials EPMA, 1997.

[7] Da Silva Bartolo, P. J.; de Lemos, A. C.; Pereira, A. M. High Value Manufacturing: Advanced Research in Virtual and Rapid Prototyping, CRC Press, 2013.

[8] Narayan, R. Rapid Prototyping of biomaterials: Principles and Applications. // Woodhead Publishing Series in Biomaterials, 2013. 
[9] Ferreira, J. C. Rapid Prototyping and 3D Scanning in the Portuguese foundry industry. // Proceedings of the $6^{\text {th }}$ European Conference on Rapid Protoryping and Manufacturing / Notthingham (UK), 1997, pp. 157-166.

[10] Greenbaum, P.; Khan, S. Direct Investment Casting of RP Parts. // Proceedings of the $5^{\text {th }}$ European Conference on Rapid Prototyping and Manufacturing / Nottingham (UK), 1993, pp. 77-94.

[11] Nutt, K. The SLS Selective Laser Sintering Process. // Proceedings of the $1^{\text {st }}$ European Conference on Rapid Prototyping / Nottingham (UK), 1992, pp. 51-58.

[12] Warner, M. Metal Rapid Prototyping methods and case studies for metal casting and tooling. // Time-Compression Technologies. 6, 5(1998), pp. 45-51.

[13] Băilă, D. I. Biomaterials processing by RP technologies used in the implants manufacturing // DAAAM 2012/ Zadar, 2012, pp. 285-288.

[14] Boutrand, J. P. Biocompatibility and performance of medical devices. // Woodhead Publishing Series in Biomaterials, 2012. DOI: 10.1533/9780857096456

[15] Băilă, D. I. Sintered compacts of titanium-hydroxyapatite used in medicine. // Applied Mechanics and Materials Journal. 467, (2013), pp. 192-197. DOl: 10.4028/www.scientific.net/AMM.467.192

[16] Băilă, D. I. Researches concerning the phenomena at the interface for the sintered compacts if titan-hydroxyapatite. // Advanced Materials Research Journal. 856, (2013), pp. 164-168. DOI: 10.4028/www.scientific.net/AMR.856.164

[17] Thaveedeetraku, A.; Witit-Anun, N.; Boonamnuayvitaya, V. Effect of Sputtering Power on in vitro Bioactivity of Zirconia Thin Films Obtained by DC Unbalanced Magnetron Sputtering. // J. Chem. Eng. Jpn. 46, (2013), pp. 79-86. DOI: $10.1252 /$ jcej.12we088

[18] Denry, I.; Kelly, J. R. State of the Art of Zirconia for Dental Applications. // J. Dent. Mater. 24, (2008), pp. 299-303. DOI: 10.1016/j.dental.2007.05.007

[19] Harmand, M. F. In vitro study of biodegradation of a $\mathrm{Co}-\mathrm{Cr}$ alloy using a human cell culture model. // J. BiomaterSciPolym Ed. 6, 9(1995), pp. 809-814. DOI: 10.1163/156856295X00193

[20] Xu, R.; Wu, G.; Yang, X.; Hu, T.; Lu, Q.; Chu P. K. Controllable degradation of biomedical magnesium by chromium and oxygen dual ion implantation. // Materials Letters. 65, (2011), pp. 2170-2173. DOI: 10.1016/j.matlet.2011.04.043

[21] Boutrand, J. P. Biocompatibility and performance of medical devices. // Woodhead Publishing Series in Biomaterials, 2012. DOI: 10.1533/9780857096456

[22] Ayyıldız, S.; Soylu, E. H.; İde, S.; Kılıç, S.; Sipahi, C.; Pişkin, B.; Gökçe, H. S. Annealing of Co-Cr dental alloy: effects on nanostructure and Rockwell hardness. // Journal of Advanced Prosthodontics. 5, 4(2013), pp. 471-478. DOI: 10.4047/jap.2013.5.4.471

\section{Authors' addresses}

Diana-Irinel Băilă, PhD. Eng.

University POLITEHNICA of Bucharest,

313, Spl. Independentei, district 6, 060042, Bucharest, Romania baila_d@yahoo.com

Oana-Cătălina Mocioiu, PhD. Eng.

"Ilie Murgulescu" Institute of Physical Chemistry of Romanian Academy,

202, Spl. Independentei, district 6, 060021, Bucharest, Romania oana.mocioiu@yahoo.com

\section{Roxana Truşcă, PhD. Eng.}

METAV CD,

31, Rosetti, district 2, 20011, Bucharest, Romania

truscaroxana@yahoo.com

\section{Adrian Surdu, Drd. Eng.}

University POLITEHNICA of Bucharest,

313, Spl. Independentei, district 6, 060042, Bucharest, Romania adrian.surdu@live.com

\section{Cătălin Zaharia, PhD. Eng.}

University POLITEHNICA of Bucharest,

313, Spl. Independentei, district 6, 060042, Bucharest, Romania zaharia.catalin@gmail.com

\section{Mihaela Bunea, Drd.Eng.}

University POLITEHNICA of Bucharest,

313, Spl. Independentei, district 6, 060042, Bucharest, Romania buneamihaelacristina@yahoo.ro 